\title{
Investor-State Dispute Prevention: The Perspective of Peru
}

\author{
Carlos José Valderrama
}

\section{Contents}

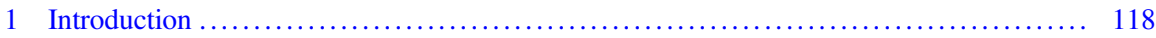

2 Facts and Risks to Take into Account ....................................... 119

2.1 Prevention: The Aim Is No Disputes .................................. 119

2.2 The Risk Is Permanent .......................................... 120

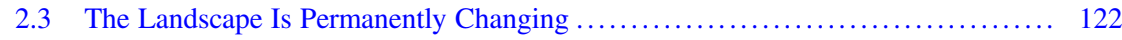

2.4 ISDS in Light of Important Cultural and Practical Differences .................. 124

2.5 States as Subjects of International Law .............................. 125

3 Model and Practices Developed by the Republic of Peru during 2011-2015 ........... 126

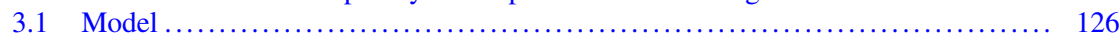

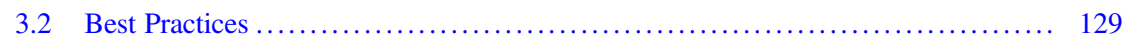

4 Fundamental Considerations and Recommendations for the Prevention of Disputes ..... 130

$4.1 \quad$ Some Further Considerations ........................................ 130

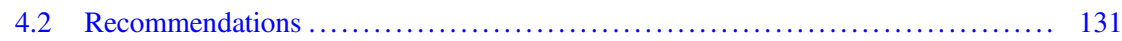

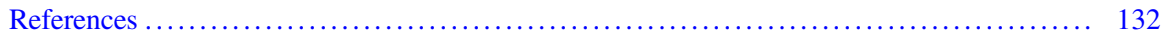

\begin{abstract}
This chapter examines state perspectives on investor-state dispute prevention drawing on the author's personal experience and practice in Peru's legal defence team. First, it focuses on identifying risks states experience when confronted with investor-state dispute settlement. Next, the chapter turns to particular experiences and general considerations regarding dispute prevention. Finally, it concludes with some recommendations for the implementation of certain dispute prevention practices.
\end{abstract}

This chapter draws on the author's experience as head of Peru's legal defence team between 2011 and 2015. The author would like to thank Maria Fernanda Bonilla Vargas and Yurica Ramos Montes for their generous assistance and research.

C. J. Valderrama $(\square)$

Independent Practitioner, Washington, DC, USA

(C) The Author(s) 2021

C. Titi (ed.), Public Actors in International Investment Law, European Yearbook of International Economic Law, https://doi.org/10.1007/978-3-030-58916-5_7 


\section{Introduction}

Between 2011 and 2015, Peru was ordered to pay compensation to foreign investors equal to just about $0.002 \%$ of the total sum claimed against it (50 US billion dollars). At the same time, the state received 140 times the amount paid to investors (110 US million dollars) by initiating claims and counterclaiming against investors, in a total of nine investor-state arbitration awards. ${ }^{1}$ The record appears to be impressive, without any doubt, but it is still far from optimal. The optimal should be no disputes at all, with the international responsibility and reputation of the state never at risk.

Favourable awards are highly valuable, they emphasise how responsive and respectful a state is regarding certain standards of investment protection and can become evidence of its good performance in protecting foreign investors in its territory. Awards can (and should) be used, by states, as favourable "precedents" when facing new disputes. Nevertheless, not being challenged has, literally, no price. It may seem very improbable but that should always be the objective for states: no disputes.

In the real world, relations between state representatives and private investors entail, by definition, the overly complex and careful practice of communicating their mutual, but opposite, interest in the same businesses (or projects). For instance, it is frequent that investors' interests directly collide with public interests such as those of their workers, suppliers, and/or local communities, as they represent social costs that investors are usually inclined to argue should be carried by the state.

At the other end of the spectrum, state officials often seem to be more concerned about their own job stability and personal responsibility rather than the real longterm benefits their decisions represent for the state. ${ }^{2}$ When engaging in projects with private investors intended to benefit the public interest, frequently, state representatives appear to be more centred on immediate personal success rather than on carefully assessing the overall longer-time effects of such projects.

Regarding public-private partnerships (PPPs) or concession contracts, when unfortunate events occur and action needs to be taken, terms seem to be differently interpreted by the parties. The ultimate question of whether it is the state or the investor that should assume the costs of undesired and unexpected events is hardly answered by the sole text of contract provisions. Sooner or later, one of the disputing parties tends to resort to dispute resolution. Let us not forget that investors are allowed to do whatever is not forbidden and state officials only what is expressly authorised by law.

Following a few notices of intent and arbitration requests, state officials would easily notice that many times counsel for the investors use these documents as lottery cards, since they tend to disaggregate every single state action related to the dispute

\footnotetext{
${ }^{1}$ See https://www.mef.gob.pe/es/acerca-de-las-asociaciones-publico-privadas-apps/sicreci.

${ }^{2}$ Chew et al. (2018).
} 
and link it to the breach of a standard of protection in an investment treaty. For this reason, claims initiated under investment treaties become unnecessarily long and complex; the state usually needs to respond to each claim individually.

\section{Facts and Risks to Take into Account}

States need to use realistic and applied practices in order to prevent disagreements from escalating into full-blown disputes. This section proposes some fundamental issues states may wish to consider for the prevention of investor-state disputes.

\subsection{Prevention: The Aim Is No Disputes}

Disputes are better when avoided. The cost of a dispute is generally high, since it entails, not only the money and time spent litigating but, mostly, the costs involved in complying with the award, in case the state loses the dispute. Most probably, any of these costs could be lowered if the dispute is avoided or settled at an early stage; in other words, when it is still "potential".

The reputational cost, for the state, should also be taken into account. This is a variable the state should consider very carefully, because it always adds to other variables that the international community, multilateral and commercial banks, and other lenders, as well as foreign investors generally take into account. In the case of a government committed to managing an economic crisis and in the midst of that crisis, international claims start to arise, ${ }^{3}$ credit can become scarcer and more expensive, and crisis management becomes more difficult for the government. ${ }^{4}$

Among the many types of disputes states face, investor-state disputes are not the most difficult to resolve. For example, investor-state disputes can still be prevented and managed on a case by case basis, due to the relatively low number of cases. On the contrary, social unrest, such as workers' unions' and consumers' protests, are much more difficult to identify, assess, prevent, and resolve than investor-state disputes. Social actors can have so many more different motivations than investors, such as political or personal interests or even corruption, and unrest may be evidence of a broader unease and dissatisfaction that can lead to violence.

The real problem occurs when popular unrest lies at the origin of state measures that trigger investment disputes. In such cases, states must explain to an arbitral tribunal, composed by foreign individuals, the profound nature and history of a specific social conflict and why the measures adopted to appease the angry crowd are

\footnotetext{
${ }^{3}$ Simões (2012), pp. 9-37.

${ }^{4}$ Franck (2011).
} 
justified, even if they affect investments. This can be particularly hard to do. ${ }^{5}$ In such cases state representatives will need to coordinate their actions, statements and strategies very carefully in order to avoid exposing internal conflicts before international arbitral tribunals. In other words, internal conflicts can exacerbate investorstate disputes.

Again, foreign investors' claims are much easier to identify and manage than internal conflicts. Engaging in a dialogue with a company bringing a dispute requires one phone call. There may be many foreign investors in each country, but not all of them have potential or pending disputes against the state. In order to better "manage" foreign investment, states could think about establishing records of foreign companies and other investors in their territories and follow up systematically and statistically. This will allow the state to efficiently identify potential conflicts that may escalate into international disputes in the near future.

Furthermore, dispute resolution mechanisms included in investment treaties, offer a valuable window of time for states, known as consultations or cooling-off periods that, if responsibly used, may avoid the initiation of an arbitration. ${ }^{6}$ The consultations period is a "golden" opportunity for states to formally determine the settlement procedure in accordance to their own practice and timing preferences and do their best efforts to settle the dispute. It is a period of time, usually six months long, that is not regulated by the dispute resolution provision and during which disputing parties usually approach each other to jointly agree on the next steps to be taken to reach a solution. This approach often fails, for many reasons. But if the state has a previously organised strategy, offering the investor a pre-designed settlement protocol and schedule, the state may have the opportunity to have a better control over this period and the dispute, and resolve it at that stage.

\subsection{The Risk Is Permanent}

Democracy, entails that every citizen has the right to be considered for public office or post, irrespective of his or her political views, approach to private investment, sympathy or antipathy towards a determined group, profession, or minority, or even level of academic education. During the last few years, we have been able to observe how constituencies in different countries have supported leaders and representatives with protectionist views and preferences, promising voters to defend their industries and products against foreign industries and importers. This worldwide observed phenomenon keeps relations with foreign investors unstable; even where investorstate dispute settlement (ISDS) has made states internationally accountable for any mistreatment of foreign investors.

\footnotetext{
${ }^{5}$ Bear Creek Mining v. Peru, ICSID Case No. ARB/14/21, Award, 12 September 2017.

${ }^{6}$ Schreuer (2005); Sharma (2019), pp. 138-152.
} 
Even though, states are permanently seeking to improve their relations with foreign investors by opening and promoting markets and/or by offering fiscal stimuli, among other investment-attraction policies, those relations still need to improve since they are always sensitive. The state should never assume that its actions and decision-making processes will improve any time soon (nor the investors'). States and investors' representatives are not being replaced by better prepared and more sophisticated ones. For that reason, it would be useful to implement a more institutionalised, permanent system to allow the state to consolidate its position and arguments, when an investment dispute arises.

As will be explained below in more detail, the Republic of Peru found it extremely useful to create a unit with the express mandate to represent the state in investor-state disputes and coordinate its participation and defence. ${ }^{7}$ This unit is the judge of its own competence, it possesses exclusive representation powers, and it has the ability to determine the responsibility of those public officials and entities that generated the dispute and/or refused to cooperate for the defence of the state. This special unit provides the state with a strong capability to assess its relations with investors in different public and economic sectors and collaborate with the relevant officials in order to find creative ways to prevent and resolve potential disputes, by reacting efficiently in a timely manner and in a case-by-case scenario.

After a few years, the unit was able to identify numerous examples of public officials' behaviours creating significant risks for the state of not only being involved in international disputes but of also making disputes more costly and hard to defend. In particular:

1. Newly appointed political authorities often make decisions miscalculating their consequences, since they are often unaware of the existence of international investment agreements (IIAs) and the investor-state dispute resolution mechanisms contained in them.

2. Similarly, sometimes authorities exaggerate their confidence regarding their ability to resolve potential disputes. The problem arises when they become aware of their inability to solve the dispute and it may be too late to prevent the arbitration, since the arbitration initiation notice has already arrived.

3. Frequent renewal of public appointments also changes ministry priorities and creates potential miscommunications with investors and other stakeholders. It is also common that newly-appointed officials have no clarity over any agreement their predecessors were reaching with foreign investors or that they simply do not agree with its terms.

4. It is also frequent that high-ranking bureaucrats tend to avoid certain decisions, because they may entail personal responsibility, or even criminal liability, for any mistake incurred.

5. Many times, public officials are not aware that their internal communication exchanges could be used as evidence in an investor-state arbitration.

\footnotetext{
${ }^{7}$ See https://www.mef.gob.pe/es/obras-por-impuestos/documentos-importantes?id=377.
} 
6. Most of the time, contracts are poorly drafted and their interpretation is even worse.

7. Occasionally, public officials endeavour to stamp their personal and political ideologies in their offices and positions, instead of acting neutrally in representation of the state.

Those are real situations that make state defence extremely difficult and expensive. It is important to remember that, when facing an international dispute, states not only confront the difficulties that the facts of the dispute represent but also, since bureaucratic processes are slow and involve several actions and actors, these processes can potentially create further risks.

For these reasons, states could seriously reflect on the possibility of creating a specialised unit centralising the internal coordination and representation related to investor-state disputes, in order to ensure sufficient flexibility and space to react in a timely manner and prevent potential disputes. The more practice and experience the unit and the state acquire, the most successful the prevention of disputes becomes. There are no spell books granting states the power to prevent disputes. All depends on their practice and experience.

\subsection{The Landscape Is Permanently Changing}

Investment protection is not a new phenomenon in the international sphere. In the early 1600s' trading monopolies were granted by sovereigns to a few companies owned by independent investors who, directly and even personally, assumed the risks of exploring, settling and developing successful mercantile activities overseas. ${ }^{8}$ Four centuries later, after joining efforts in different ventures, including expeditions and wars, relations between sovereigns and their national private investors evolved into investor-state relations as we know them today; sovereigns signed treaties between them allowing their national investors to directly initiate disputes against those other sovereigns that breach certain agreed standards of protection. ${ }^{9}$

In the last few years, there has been an explosive growth of a new generation of companies in almost every sector of the world's economy. ${ }^{10}$ From the rise of

\footnotetext{
${ }^{8}$ Brown (2010), p. 1.

${ }^{9}$ UNCTAD have registered 2,897 bilateral investment treaties and 390 treaties with investment provisions so far. See https://investmentpolicy.unctad.org/international-investment-agreements.

${ }^{10}$ Byanyima Winnie (2017) 8 Men Have the Same Wealth as 3.6 Billion of the World's Poorest People. We Must Rebalance this Unjust Economy", World Economic Forum https://www. weforum.org/agenda/2017/01/eight-men-have-the-same-wealth-as-3-6-billion-of-the-worldspoorest-people-we-must-rebalance-this-unjust-economy/; Tavierne Randall (2018) How Private Companies Are Driving Growth, EY Building a Better Working World, https://www.ey.com/en gl/growth/how-private-companies-are-driving-growth; OECD (2018) Multinational enterprises in the global economy heavily debated but hardly measured, https://www.oecd.org/industry/ind/ MNEs-in-the-global-economy-policy-note.pdf; OECD (2002) Foreign direct investment for
} 
internet giants, the growth of mining, pharmaceutical and infrastructure companies, to jet builders, airlines, mobile phones, and film producers. The value that these companies represent to their sovereigns in terms of jobs, tax collection and technological improvement appears to be critical for their national economies. For this reason, investment recipient states should ponder on these last few years' events and seriously consider that it is highly possible that sovereigns (home states) may be willing to protect their national investors and their investments abroad.

States find it increasingly difficult to control companies' mergers, or to adapt their tax systems to new realities; ${ }^{11}$ corruption can affect governments' stability, and companies bring multi-billion claims against states before arbitral tribunals under the aegis of the International Centre for Settlement of Investment Disputes (ICSID). ${ }^{12}$ These facts suggest that foreign investors' leverage vis-à-vis national and foreign governments is increasing too. It is important to notice that, through the agreed investor-state dispute resolution mechanisms, states have started to grant investors the right to initiate disputes against them on public international law grounds. ICSID awards are internationally binding; ${ }^{13}$ if a state fails to comply with an ICSID award, then the investor's home state will be able to initiate countermeasures against the defaulter.

We can also identify other initiatives designed to balance international relations due to the new relevance of a company at the international level. The Organisation for Economic Co-operation and Development (OECD) is promoting a model convention to create an international taxation system, ${ }^{14}$ looking forward to adjusting online companies' income tax collection to an effective territorial reality. The United

development maximising benefits, minimizing costs, https://www.oecd.org/industry/inv/ investmentfordevelopment/1959815.pdf; UNCTAD (1998) Foreign direct investment on the rise, https://unctad.org/en/pages/PressReleaseArchive.aspx?ReferenceDocId=3173; United Kingdom, Department for International Development (2011) The engine of development: The private sector and prosperity for poor people, https://assets.publishing.service.gov.uk/government/uploads/ system/uploads/attachment_data/file/67490/Private-sector-approach-paper-May2011.pdf; Fortune, 100 Fastest-Growing Companies https://fortune.com/100-fastest-growing-companies/2019/momo/; Forbes, Most Innovative Growth Companies https://www.forbes.com/growth-companies/list/\#tab: rank.

${ }^{11}$ The Economist (2019) France's digital tax riles the White House, https://www.economist.com/ finance-and-economics/2019/07/11/frances-digital-tax-riles-the-white-house.

${ }^{12}$ Orta David, Allegations of Corruption in Investment Treaty Arbitration: The Need for Reform https://www.expertguides.com/articles/allegations-of-corruption-in-investment-treaty-arbitrationthe-need-for-reform/arkesfdy.

${ }^{13}$ Article 54(1) of the Convention on the Settlement of Investment Disputes between States and Nationals of Other States (ICSID Convention) provides: "Each Contracting State shall recognize an award rendered pursuant to this Convention as binding and enforce the pecuniary obligations imposed by that award within its territories as if it were a final judgment of a court in that State. A Contracting State with a federal constitution may enforce such an award in or through its federal courts and may provide that such courts shall treat the award as if it were a final judgment of the courts of a constituent State".

${ }^{14}$ See http://www.oecd.org/tax/model-tax-convention-on-income-and-on-capital-condensed-ver sion-20745419.htm. 
States of America is actively prosecuting corruption outside its borders through the Foreign Corrupt Practices Act (FCPA). ${ }^{15}$ In fact, most, if not all, of the corruption scandals of the last few years were uncovered by the application of this act.

In short, investors may have better leverage than they did a few years ago, and this may improve in the near future. States are urged to establish clear rules, relations, and commitments, or dealing with investors may become expensive in the future. It would be advisable for states to consider establishing a record of the foreign companies investing in their territories and to monitor their activities, engaging in a permanent open dialogue, in order to be capable to take the right measures at the right time to prevent disputes. Among some suggested measures, we could mention:

1. The creation of a special unit to be exclusively devoted to research, assessment and the drafting of concession contracts, including amendments. In other words, states could consider building a flexible concession contract model. This unit should be professionally prepared and have the capacity to act across all state entities, including central and local governments. Moreover, it should be in permanent dialogue with concessionaires, keeping contracts open to discussion for adjustments and improvements to the benefit of both parties.

2. The creation of a register of foreign privately-held companies entering their economies and following-up with them periodically, opening a window of dialogue with them (like customer service).

3. Periodically the state could assemble all public officials related to foreign investors and establish open discussions with them, assessing all the different problems they face, introducing mechanisms to allow collaboration with them in order to prevent disputes and possibly granting them the legal tools they need to successfully deal with investors.

\subsection{ISDS in Light of Important Cultural and Practical Differences}

It is important at this point to consider cultural differences when facing an international dispute. Different cultures and nations have different approaches to the concept of investment and the role of the state in relation to it; the same occurs with dispute resolution, and its particularities. In fact, the approach to private-public relations is different, even within the same regions. State officials must be aware of the fact that, when reaching arbitration, the dispute may be resolved under a totally different and strange environment for them, where not only cultural differences between the state and investors become clear but also differences between counsel, legal and procedural traditions, and arbitrators' backgrounds. Therefore, when making the decision to pursue an international arbitration, it may be better to be

\footnotetext{
${ }^{15}$ The United States Department Stares (2017) Foreign Corrupt Practices Act. https://www.justice. gov/criminal-fraud/foreign-corrupt-practices-act.
} 
aware of the extra costs these variables involve. For these reasons, state representatives should be conscious of the fact that foreign investors are culturally different to them. In that sense, notices and communications should be kept as clear, direct and objective as possible, in order to avoid misrepresentations or future misunderstandings with investors, legal counsel and arbitrators.

An important reason to consider avoiding international investor-state disputes is the fact that the state will be navigating in strange waters, incapable of completely understanding the context where its dispute is being resolved. As a rule, arbitrators are not nationals of the disputing parties, ${ }^{16}$ but can be of the same nationality as counsel and the experts retained by the parties, the latter representing a potential closer common understanding regarding several variables discussed in the dispute, including procedural customs. For example, international arbitration as an adversarial system is not the same as the civil law litigation inquisitorial system. It is particularly important for state representatives to consider these facts when assessing whether to pursue an international arbitration or to aim to settle the issue before it escalates into a full-blown dispute.

\subsection{States as Subjects of International Law}

A key issue to take into consideration is that investment arbitration may be the forum where states are the most vulnerable (apart from international courts). Under public international law, states' decisions, actions and public statements bind them legally. ${ }^{17}$ In this forum, the state is not understood as the current government, where recentlyappointed officials can blame their predecessors for their mistakes, faults or incompetence. In international arbitration, new governments will always need to defend the mistakes committed by their predecessors, as if they are their own. Relatedly, since states are usually divided in regions and provinces, and regional and provincial authorities also represent and internationally bind the state, permanent and close coordination with subnational governments is fundamental to avoid disputes and further international claims.

\footnotetext{
${ }^{16}$ Titi (2020), p. 43.

${ }^{17}$ Dumberry (2016).
} 


\section{Model and Practices Developed by the Republic of Peru during 2011-2015}

\subsection{Model}

Like several other states, the Republic of Peru finds itself immersed in ISDS cases. ${ }^{18}$ It has signed around 40 IIAs $^{19}$ and hundreds of contracts with foreign investors, granting protection to their investment and consenting to solve any related dispute in international arbitration. It is interesting to note that Peru grants access to international arbitration under ICSID and under the Arbitration Rules of the United Nations Commission on International Trade Law (UNCITRAL) in most of its concession contracts, which, as I will explain later, is a very healthy policy for the prevention of disputes. $^{20}$

In order to manage the defence of its interests in international arbitration, Peru established a coordination and response system called SICRECI (Sistema de Coordinación y Respuesta del Estado en Controversias Internacionales de Inversión) with the mandate to represent the state, from the reception of the investor's notice of dispute until the compliance with and enforcement of the final award terminating the dispute. ${ }^{21}$ The system is aimed to carry out all the internal coordination efforts among all the entities that may have a direct or indirect role in the disputed facts and in the conduct of the defence strategy, in close coordination with the legal team that represents Peru before the international tribunal. ${ }^{22}$

Act 28933 of 2006, which established the SICRECI, ${ }^{23}$ also created a Special Commission. $^{24}$ The coordination mechanism is quite simple. The Special Commission centralises the defence of the state by acting as its exclusive representative before the disputing investor and arbitral tribunal. As soon as the investor notifies the state of the initiation of the dispute, the Special Commission requests the relevant entities to submit their legal opinion about the dispute, with a detailed explanation of the facts, all the relevant documents and their institutional position in relation to the dispute.

With both elements at hand (the notice of dispute and the entity's opinion), the Special Commission decides on its own competence. If the dispute is considered to

\footnotetext{
${ }^{18}$ Peru's website of the Minister of Economy and Finance reveals a total of 16 cases that have been concluded by 2019. See https://www.mef.gob.pe/es/acerca-de-las-asociaciones-publico-privadasapps/sicreci.

${ }^{19}$ See https://www.mef.gob.pe/es/obras-por-impuestos/estadisticas/197-inversion-privada/ acuerdos-y-convenios-de-promocion-y-proteccion-rec/343-listado-de-acuerdos-y-convenios-depromocion-de-inversiones.

${ }^{20}$ Valderrama (2018), p. 105.

${ }^{21} \mathrm{See}$ https://www.mef.gob.pe/es/acerca-de-las-asociaciones-publico-privadas-apps/sicreci.

${ }^{22}$ Peru, Supreme Decree No. 002-2009-EF, 13 January 2013.

${ }^{23}$ Peru, Act No. 28933, 15 December 2006.

${ }^{24}$ Article 7 of Act $\mathrm{N}^{\circ} 28933,15$ December 2006.
} 
be an investor-state dispute, then the Special Commission is competent to represent the state; on the contrary, if it is considered a commercial controversy, the entity directly involved in the dispute will be responsible for its own defence with its own means and budget.

Once the competence is decided by the permanent members of the Special Commission, ${ }^{25}$ the Special Commission invites the relevant entities that are involved or have contributed to the escalation of the conflict to join it. ${ }^{26}$ Immediately after that, it proceeds to invite the investors to an introductory session, allowing them to explain their concerns, points of view and claimed damages. After careful consideration, the Special Commission sends a written response, proposing the formal initiation of the settlement process or expressing the contrary position of the state, offering the claimant investor a chance to rebut the state's position. These actions indicate the initiation of the cooling-off period. ${ }^{27}$

If a formal invitation to initiate a negotiation process is sent, a signed one-page "Negotiation Protocol" is attached to the letter of invitation, containing the basic rules for the negotiation process. That document is to be signed and returned to the Special Commission in order to initiate the settlement. On the contrary, if the Special Commission decides that a settlement is not possible, it will communicate its decision to the investor. When appropriate, the Special Commission, as the exclusive representative of the state, withdraws the right of the state to continue with the cooling-off period and offers the investor the opportunity to immediately initiate the arbitration proceedings.

Depending on the nature of the dispute and the investor, the dialogue continues or is discontinued until the initiation of the arbitration. Often the cooling-off period is a very active stage of the process and sometimes it is very efficient to resolve the dispute. On other occasions, even though the dispute is not resolved, it is still very helpful to substantially reduce the damages claimed.

Once the dispute is initiated, a well-managed cooling-off period is the best method to prevent an arbitration. That is the reason of its mere existence: a reasonable period of time for both parties in a dispute to make their best efforts to settle their differences. It is key for the state to take advantage of this period and really endeavour to terminate the dispute and avoid the arbitration. Cooling-off periods typically last for six months, which is not a long period. Many times, when true efforts are made, parties find out that they may need more time to continue with the process and, assuming that both parties are engaged in trying to achieve a solution, they mutually consent to extend the cooling-off period until a solution is reached. The Special Commission is habilitated to seek an agreed solution with the investor and, once a reasonable solution is agreed, authorisation from the cabinet of ministers will be needed to sign the settlement agreement.

\footnotetext{
${ }^{25}$ Article 7.3 of Act No. 28933, 15 December 2006.

${ }^{26}$ Article 7.3 (f) of Act No. 28933, 15 December 2006; See Supreme Decree No. 125-2008-EF, 13 January 2013.

${ }^{27}$ Schreuer (2005); Sharma (2019), pp. 138-15.
} 
A few other times, public officials admit their mistakes and, by making a sincere effort to better understand the investor's viewpoint, change their positions conceding the investor's request. Here the case is solved in the most efficient manner. In these cases, the Commission's work consists in approaching the parties in conflict and allowing them a space to calmly discuss. In any case, the great advantage of a disciplined handling of the cooling-off period is that, if an arbitration commences, the state is not taken by surprise but is on the contrary well-prepared to successfully respond before an international arbitral tribunal.

Act 28933 stipulates that the state's response system covers two levels of actions to be accomplished by the Special Commission: ${ }^{28}$ (1) the prevention of disputes by centralising relevant information, establishing an alert mechanism and standardizing dispute resolution provisions in treaties and contracts, and (2) the management of the defence of the state's interests during the cooling-off period, and during the arbitration or conciliation. Efficient management of the defence is also key for the prevention of (other) disputes.

The centralisation of information is indeed very important. The state needs to have detailed knowledge of the content of the awards rendered in the arbitrations to which it is party. Tribunals' findings and interpretations that may be used against the state in the future are certainly very important to take into consideration. The same occurs with non-disputing parties' submissions, interpreting treaty provisions. $^{29}$ Records of settlement processes followed during the cooling-off period also help the state to learn from its mistakes and perfect its practice in order to avoid future disputes.

In addition, as a prevention practice, the Special Commission implemented a state-of-the-art online alert mechanism, with very simple and clear instructions, in order to raise the alarm of an incoming dispute. We also included a self-guided crash course on ISDS for the stakeholders concerned. Unfortunately, the system was never used and it now appears to have been removed from the government's website. It seemed that public officials were not convinced about using an online system that would create records of their actions, thus possibly protecting themselves against any presumption of responsibility for a dispute that may cost hundreds of millions of dollars to the state. Public officials may prefer to make phone calls, or visit offices, and discuss about potential disputes personally.

\footnotetext{
${ }^{28}$ Articles 7, 8 and 9 of Act No. 28933, 15 December 2006.

${ }^{29}$ State parties to a treaty that are not parties to the dispute may have a right under that treaty to make submissions on a question of application or interpretation of the treaty (see e.g. Article 1128 of the North American Free Trade Agreement (NAFTA). See also ICSID Arbitration Rule 37(2) on submissions by non-disputing party submissions. See further chapters by Rebecca E. Khan and Kendra Magraw, this volume.
} 


\subsection{Best Practices}

Settling a dispute by mutual agreement is a right that parties to a contract have from the very beginning of their contractual relationship. Mutual agreement can entail mutually adapting to the other party's position resulting in the common understanding of the contract's telos and provisions. Even before the initiation of the coolingoff period-which prevents arbitration by encouraging the parties to seek a solution within the scope of the dispute settlement provision-, there is a useful practice that can help avoid initiating or aggravating a potential international dispute: empowering public officials.

As mentioned above, Peru's Special Commission has the capacity to decide on its own competence by assessing the nature of the dispute in question. The course of such an assessment is the perfect time to work closely with the relevant state entity and its representatives to find strategies to prevent the dispute. This is also true because this is the time when the officials involved in the dispute are more concerned about its consequences and therefore they are more open to cooperating.

Often the dispute is ignited by public servants' refusal to exercise their discretion. Whether they are placed before a contract amendment, dispute settlement or any kind of mutual concession with an investor, public officials may prefer not to sign any binding document in order to avoid any allegations of corruption or to avoid being prosecuted for any losses the state may suffer. In these cases, immediate action is required. The unit responsible for the defence of the state must be ready to officially communicate to the relevant officials its concerns about the risks such actions or ommissions represent for the state, the fact that the claimant may have a strong case and, if the dispute reaches the international stage, that the damage to the state will be high and public. Such communication must expressly stablish that the more efficient and less costly approach would be for direct and discrete negotiations to be initiated in order to reach a settlement between the entity and the investor. Finally, the unit should offer its assistance with the settlement process to the relevant public entity. This action is aimed to grant sufficient support to relevant officials to initiate the settlement negotiation procedures by creating a safe environment and a presumption against corruption. The goal for the unit should be to obtain an express statement from the investors formally withdrawing their international claims against the state, so that the dispute can be archived per secula seculorum.

Another interesting practice is that Peru, as previously mentioned, includes ICSID provisions in most of its concession contracts. Since such a forum is agreed in the contract, the provision can be applied both ways ${ }^{30}$ and the IIAs' umbrella clause becomes irrelevant. ${ }^{31}$ But the most interesting fact about being able to bring a claim against an investor before ICSID is that the system offers immediate

\footnotetext{
${ }^{30}$ E.g. see Peru v. Caravelí Cotaruse Transmisora de Energía SAC, ICSID Case No. ARB 13/24.

${ }^{31}$ Sasson (2017), pp. 199-242.
} 
recognition and ultimately enforcement of its awards in 160 national jurisdictions, increasing the state's possibility of claiming against an investor far beyond its borders.

\section{Fundamental Considerations and Recommendations for the Prevention of Disputes}

Prevention turned to be a big part of the daily work of our unit. In our experience, once our unit became known across the country, it was almost permanently requested to provide advise on many different matters, from the drafting of contract provisions to complex or failing negotiation procedures. It was also asked to offer training courses and to give lectures to authorities, colleagues and teams about the risks of investment disputes and how to prevent them.

\subsection{Some Further Considerations}

States could take a few variables into consideration when planning a strategy to prevent or arbitrate investment disputes. Prevention occurs in two key areas, which will now be considered in turn.

\subsubsection{In the Context of ISDS More Generally}

When the state uses the ISDS regime to solve disputes with foreign investors, it may be prudent to develop a comprehensive plan for the overall defence of the state in this forum, considering a few wide-ranging actions that, in the mid- or long-term, would allow the state to prevent disputes easily. It would be useful to periodically remind public servants about the risks their statements and decisions represent for the state. As mentioned above, there is no guarantee that (elected) public representatives fully understand the entire consequences of their acts. Therefore, the special unit responsible of the defence of the state should be permanently "touring" the different state entities and address their members about investment dispute mechanisms and their risks.

It is very important for the state to assume a strong and assertive defence in investment cases, when prevention is not possible, and to confidently face investors. It is important that the investors' community perceives the state as strong and hard to prevail against, in the case of a dispute. The state should remind investors that ISDS is also of high risk for them too. This stance should be intended to discourage investors with frivolous or not-so-strong claims from initiating arbitrations against the state. 
The state would like to develop a uniform position regarding investment arbitration and be consistent with it. It may not be wise to be a party to investment arbitration procedures and criticise the mechanism in other fora, since this may create contradictions and bad relations with tribunals. If the state actively uses the mechanism, it would be wise to focus its efforts on fully understanding it and obtaining the best possible results. If, on contrary, the state rejects the mechanism, then it should do its best not to be challenged before it, and withdraw from every provision that ties it to its tribunals, or in any case amend such provisions in a manner that may satisfy its needs. But if it is not consistent with its position and statements in different fora can be perceived by tribunals as contradictory, this may weaken the state's defences in its disputes. It is also key to always comply with awards and enforce them when appropriate. A good reputation has no price before a tribunal. That tribunals are able to recognise that a particular disputing state party is fair and respectful may influence on how they decide the dispute.

\subsubsection{In the Context of a Particular Dispute}

As already mentioned, it is of the utmost importance to pay immediate attention to the threat of initiation of a dispute and react without delay. Many disputes can be avoided with simple acts at the appropriate time. When the dispute is at its early stages, the defence team can cooperate within the state in order to enhance its ability to achieve a negotiated solution to the dispute that would prevent future international responsibility of the state. The same is true with respect to the cooling-off period, since a well-managed consultations period may avoid the initiation of an arbitration or improve the outcome of the arbitration.

It is also key for the state to establish its position in relation to the dispute, facts and the investor's claims and arguments and organise its defensive strategy accordingly. Otherwise it would be difficult to organise an effective defence. The three following facts should be kept in mind: first, the claimant always has a position in relation to the dispute; not having a position, puts the state at a serious disadvantage when negotiating or organising its defence; second, the decision on the state's position should never be delegated to the lawyers; on the contrary, the lawyers must defend the position of the state, or the proceeding will become too expensive; third, initially the position may be erroneous and, if so, it can be corrected; on contrary if there is no position, there will be nothing to correct or improve.

\subsection{Recommendations}

This chapter will close with some recommendations on how to build an efficient dispute prevention mechanism. Such a mechanism should have the following characteristics: 
1. The system and its organs (coordination \& response unit) should be created by law to avoid political criticism regarding its outcomes. Creating a system of defence supported by a thoroughly discussed law, issued by the legislative power, should reduce the risks of political challenge to the defence arguments and strategies, avoiding internal conflicts that may weaken or challenge the position of the state before investment tribunals.

2. A flexible defence structure capable of deciding its own competence. This is what allows the specialised unit to act autonomously and, by doing so, to provide assistance to other public entities. As previously mentioned, Peru's Special Commission's capacity to determine its own competence offered the state the opportunity to empower public officials and help them to prevent investment disputes.

3. Exclusive representation of the state vis-a-vis the investor and the dispute with the express ability to negotiate on behalf of the state. The unit responsible for the representation of the state should be allowed to react rapidly and to act autonomously as the exclusive representative of the state. If the unit is subject to bureaucratic procedures, then the system turns out to be useless.

4. Ability to control and unify public statements related to the dispute.

5. Ability to determine responsibility for causing the dispute and for lack of cooperation for the state's defence, and ability to request information, advice and cooperation from all public entities and officials. In the case of Peru's Special Commission, this served to persuade public officials that, contrary to their beliefs, they would become seriously liable for not settling the dispute immediately and avoiding international arbitration.

6. Ability to approve funds and hire professionals for the defence.

7. Finally, it is important to include arbitration provisions in concession contracts. These allow the state to internationally pursue damages from investors who breach the contract. This requires the decision from the state to use ISDS to its benefit which could turn out to be the best development for a state in the field of investor-state arbitration.

\section{References}

Brown SR (2010) Merchant Kings - when companies ruled the World 1600-1900. Bloomsbury

Chew S, Reed L, Thomas JC (2018) Report: survey on obstacles to settlement of investor-state disputes. NUS - Centre for International Law Working Paper 18/01

Dumberry P (2016) State practice. In: The formation and identification of rules of customary international law in international investment law. Cambridge studies in international and comparative law. Cambridge University Press, Cambridge, pp 116-291

Franck SD (2011) Rationalizing costs in Investment Treaty Arbitration. Washington and Lee University School of Law, Lexington

Sasson M (2017) Treaty versus contract claims, and umbrella clauses: when a contract breach may become a treaty breach. In: Sasson M (ed) Substantive law in investment treaty arbitration: the unsettled relationship between international law and municipal law, vol 21. Kluwer Law International, Alphen aan den Rijn, pp 199-242 
Schreuer C (2005) Calvo's grandchildren: the return of local remedies in investment arbitration. Law Pract Int Court Tribunals 4(1):1-17

Sharma A (2019) Interpretation of the cooling-off period in the Energy Charter Treaty. In: Brekoulakis S (ed) Arbitration: the international journal of arbitration, mediation and dispute management, vol 85(2). Wolters Kluwer, Alphen aan den Rijn, pp 138-152

Simões J (2012) Arbitration as a method of settling disputes arising under sovereign bonds. Revista Brasileira de Arbitragem IX(33):9-37

Titi C (2020) Nationality and representation in the composition of the international bench: lessons from the practice of international courts and tribunals and policy options for the multilateral investment court. CERSA Working Papers on Law and Political Science

Valderrama CJ (2018) Perú - buenas prácticas de cómo enfrentar demandas internacionales iniciadas por inversionistas privado. ICSID Rev 33(1):103-124. Winter

Carlos José Valderrama currently acts as independent counsel for international dispute prevention and resolution matters, focusing on international investment disputes arising under investment treaties and government contracts. He also acts as arbitrator and counsel in relation to international commercial disputes in various fora, including under the International Chamber of Commerce (ICC) Arbitration Rules. Prior to establishing his independent practice, Carlos José worked as counsel for the International Arbitration practices of Sidley Austin LLP and White \& Case LLP. Before that, he chaired for several years the Republic of Peru's inter-agency commission representing the state in international investment disputes. In that capacity, he oversaw Peru's defence in investment treaty arbitrations, hearing nearly US $\$ 50$ billion in claims, all of which resulted in favorable outcomes for the state. Some of those cases also involved the submission of claims and counterclaims by the state. Also, in that role, he managed complex negotiations to resolve or otherwise avert a number of international investment arbitrations, advised different state agencies on treaty and contract provisions related to dispute resolution, and assisted such agencies in evaluating risks and avoiding disputes. Before working for the Republic of Peru, Carlos José was a consultant for the World Bank and the Organization of American States (OAS) focused on rule of law and justice policy issues. He also practiced as an attorney at Navarro Abogados for 10 years, in Lima, Peru.

Open Access This chapter is licensed under the terms of the Creative Commons Attribution 4.0 International License (http://creativecommons.org/licenses/by/4.0/), which permits use, sharing, adaptation, distribution and reproduction in any medium or format, as long as you give appropriate credit to the original author(s) and the source, provide a link to the Creative Commons license and indicate if changes were made.

The images or other third party material in this chapter are included in the chapter's Creative Commons license, unless indicated otherwise in a credit line to the material. If material is not included in the chapter's Creative Commons license and your intended use is not permitted by statutory regulation or exceeds the permitted use, you will need to obtain permission directly from the copyright holder.

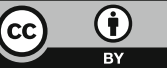

